\title{
EVELOPMENT OF AN ENVIRONMENTALLY BENIGN MICROBIAL INHIBITOR TO CONTROL INTERNAL PIPELINE CORROSION
}

\author{
TENTH QUARTER REPORT \\ (January-March 2004) \\ Prepared by
}

Bill W. Bogan, Wendy R. Sullivan, Kristine M. H. Cruz, Kristine L. Lowe, and John J. Kilbane II

DOE Award No. DE-FC26-01NT41158

\author{
GAS TECHNOLOGY INSTITUTE \\ 1700 South Mount Prospect Road \\ Des Plaines, Illinois 60018
}

GTI Project 61138 / 30793-35

April 30, 2004 


\section{DISCLAIMER}

This report was prepared as an account of work sponsored by an agency of the United States government. Neither the United States government nor any agency thereof, nor any of their employees, makes any warranty, express or implied, or assumes any legal liability or responsibility for the accuracy, completeness or usefulness of any information, apparatus, product, or process disclosed, or represents that its use would not infringe privately owned rights. Reference herein to any specific commercial product, process, or service by trade name, trademark, manufacturer, or otherwise does not necessarily constitute or imply its endorsement, recommendation, or favoring by the United States government or any agency thereof. The views and opinions of authors expressed herein do not necessarily state or reflect those of the United States government or any agency thereof. 


\begin{tabular}{|c|c|}
\hline Title: & $\begin{array}{l}\text { Development of an Environmentally Benign Microbial Inhibitor to } \\
\text { Control Internal Pipeline Corrosion }\end{array}$ \\
\hline Funding Sources: & U.S. Department of Energy and Gas Research Institute \\
\hline Contract No: & DE-FC26-01NT41158 \\
\hline GTI Project Nos: & 15317.1.01/15054.4.05 (61138-01/30793-35) \\
\hline \begin{tabular}{|l|} 
Principal \\
Investigators:
\end{tabular} & John J. Kilbane II, Ph.D. and William Bogan Ph. D. \\
\hline Report Period: & January 2004 through March 2004 \\
\hline Objective: & $\begin{array}{l}\text { The overall program objective is to develop and evaluate } \\
\text { environmentally benign agents or products that are effective in the } \\
\text { prevention, inhibition, and mitigation of microbially influenced } \\
\text { corrosion (MIC) in the internal surfaces of metallic natural gas } \\
\text { pipelines. The goal is to develop one or more environmentally } \\
\text { benign (a.k.a. "green") products that can be applied to maintain the } \\
\text { structure and dependability of the natural gas infrastructure. }\end{array}$ \\
\hline Approach: & $\begin{array}{l}\text { Previous testing of pepper extracts resulted in preliminary data } \\
\text { indicating that some pepper extracts inhibit the growth of some } \\
\text { corrosion-associated microorganisms. This quarter additional tests } \\
\text { were performed to more specifically investigate the ability of three } \\
\text { pepper extracts to inhibit the growth, and to influence the metal } \\
\text { corrosion caused by two microbial species: Desulfovibrio vulgaris, } \\
\text { and Comomonas denitrificans. }\end{array}$ \\
\hline Results: & $\begin{array}{l}\text { All three pepper extracts rapidly killed Desulfovibrio vulgaris, but } \\
\text { did not appear to inhibit Comomonas denitrificans. While corrosion } \\
\text { rates were at control levels in experiments with Desulfovibrio } \\
\text { vulgaris that received pepper extract, corrosion rates were increased } \\
\text { in the presence of Comomonas denitrificans plus pepper extract. }\end{array}$ \\
\hline Conclusions: & $\begin{array}{l}\text { Further testing with a wider range of pure bacterial cultures, and } \\
\text { more importantly, with mixed bacterial cultures should be performed } \\
\text { to determine the potential effectiveness of pepper extracts to inhibit } \\
\text { MIC. }\end{array}$ \\
\hline
\end{tabular}




\section{TABLE OF CONTENTS}

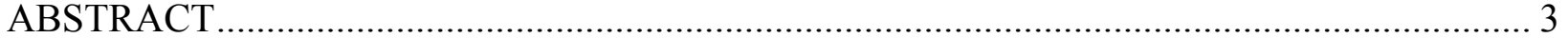

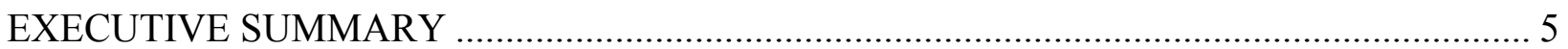

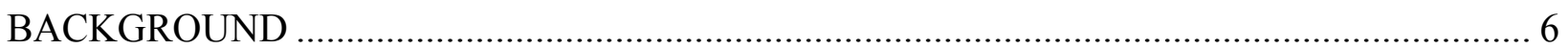

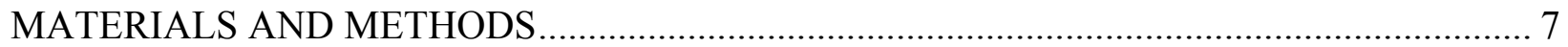

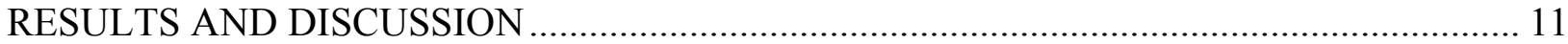

CONCLUSIONS AND FUTURE EXPERIMENTS ............................................................. 17

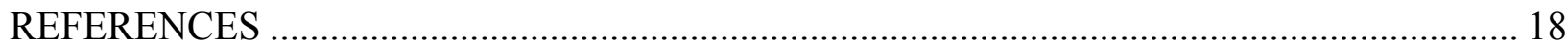




\section{EXECUTIVE SUMMARY}

The main goal of this project is to develop an environmentally benign product that could prevent and/or control microbiologically influenced corrosion (MIC) in the interior of metal gas pipelines.

The main activities for this quarter were focused on Objective No. 4, namely, the evaluation of pepper oil components to inhibit biofilm formation, bacterial survival and growth, and MIC.

Extracts from three varieties of Capsicum sp. (Chile de Arbol, Serrano, and Habanero peppers) were tested for their ability to prevent MIC in axenic cultures of one sulfate-reducing bacterium (Desulfovibrio vulgaris) and one nitrate-reducing (denitrifying) species (Comomonas denitrificans). The former of these is well-known for its involvement in MIC of gas pipelines and related structures (Chatelus et al, 1987), while the latter is among the most common species of bacterium identified in recent molecular biological analyses of bacterial communities associated with active MIC (Zhu et al, 2003); as a denitrifier, it is also a member of a bacterial class which is a known causative agent of MIC (Kholodenko et al, 2000).

Results showed that all three pepper extracts significantly inhibited corrosion caused by pure cultures of $D$. vulgaris, and that this could be readily attributed to significant toxicity of the extracts toward this species. In contrast, however, the presence of pepper extracts actually significantly stimulated biocorrosion caused by Comomonas in several cases. The exact reason for this is unclear, although it may be that Comomonas cultures can utilize the organic acid constituents of the pepper oil as sources of carbon and energy. Whatever the reason for this finding, it underscores the importance of testing putative MIC-controlling biocides against mixed cultures; as it is possible that the presence of some species (e.g. C. denitrificans) might, under the worst scenario, negate the ability of the extracts to control even those species (such as $D$. vulgaris) which are otherwise highly susceptible. Testing of extracts for MIC control under mixed-culture conditions is the current focus of our investigation. 


\section{BACKGROUND}

The overall objective of this project is to develop, test, and apply environmentally benign agent(s) to control microbial-caused corrosion on the internal surfaces of metal (iron or steel) pipes used for natural gas transmission. The overall hypothesis is that agents exist in nature that inhibit some or all of the steps executed by microorganisms in the formation of biofilm. As biofilm formation is an absolute prerequisite for the initiation and production of microbially influenced corrosion (MIC), blocking biofilm formation or propagation will block or mitigate MIC.

The general approach is to evaluate natural products isolated from plants, and, possibly, animals or microorganisms, for their abilities to block the attachment, physiology, or reproduction of microbial agents that are responsible for MIC. Thus far our search for a natural product that can inhibit MIC has focused on the compounds that can be extracted from the seeds and pods of pepper plants. These plants are members of the Genus Capsicum. The effective components or constituents of this product will then be tested for its environmental impact and effects, effective concentrations, modes of application, and stability against isolated MIC microorganisms under simulated field conditions. A commercially viable agent that aids in MIC control and is environmentally friendly is the ultimate target. 


\section{MATERIALS AND METHODS}

Pepper Extract Stock Solutions. Three extracts were selected for batch tests. The extracts and the extraction procedure were described in previous reports. Extract 1 (obtained from Chile de Arbol peppers) contained caffeic and coumaric acids as its primary identifiable constituents; extract 2 (Serrano peppers) contained several unknown organic acids; extract 3 (Habanero peppers) contained stearic, palmitic, and oleic acids. Stock solutions of $1 \%, 5 \%$, and $10 \%$ of each extract were made in hexane, and inoculated into anaerobic growth media.

Media. Anaerobic growth medium was a modification of a previously described recipe (Daulton et al., 2002). Carbon sources/electron donors consisted of: lactate, glucose, succinate, glycerol, acetate, and citrate. Electron acceptors were: sodium nitrate, sodium thiosulfate, and iron (III). Yeast extract $(0.01 \%)$ was added to provide nitrogen and to stimulate initial growth. Finally, a reducing agent $(1 \%$ thioglycollate and $1 \%$ ascorbate) was added to the final media at a ratio of 1:1000 ml.

Microbial Cultures. Bacterial cultures used were Desulfovibrio vulgaris, a sulfate-reducing bacterium, and Comomonas denitrificans, a nitrate-reducing bacterium (denitrifier). Cultures were obtained from frozen stocks maintained in our laboratory. Prior to use in experiments, aliquots of frozen cultures were transferred to $10 \mathrm{ml}$ of anaerobic growth medium and allowed to grow for 1 week (starter cultures).

Plate Counts and Most Probable Numbers Analyses. Microbial population size was estimated by either standard plate counts (C. dentrificans) or by Most Probable Numbers (MPN) analyses ( $D$. vulgaris). For plate counts, $100 \mu \mathrm{l}$ samples from each batch test were serially diluted and spread onto solid R2A agar plates (Difco Laboratories; Detroit, MI). Plates were incubated for 7 days in an anaerobic chamber after which plates having between 30 -300 colony forming units (cfu) were counted. The population size of the culture was estimated by multiplying the number of cfu by the dilution factor. For MPN estimates, a 1-ml sample of each batch test was added to $10 \mathrm{ml}$ of modified Postgate's B medium (Dixie Testing \& Products; Houston, TX); $1 \mathrm{ml}$ of the resulting bacterial suspension was sequentially diluted by $10 \mathrm{X}$ increments to a final $10^{-5}$ or $10^{-12}$-fold 
dilution. Each series was performed in triplicate. Anaerobic dilution tubes were scored for SRB by noting the presence of a black FeS precipitate after 14 days at $26^{\circ} \mathrm{C}$. MPN were determined using the program MOST PROBABLE NUMBER CALCULATOR ${ }^{\circ}$ Version 4.04 (Klee, 1996).

Analytical Methods. Concentrations of sulfide (produced from sulfate reduction), nitrite (produced from nitrate reduction), and $\mathrm{Fe}^{2+}$ (produced from iron reduction) were determined using previously published colorimetric/spectrophotometric protocols. In addition, samples were assayed for total protein content. Total protein was measured by the Lowry method (Lowry, 1951); sulfide was measured using the methylene blue method (Clesceri et al., 1998); iron (II) was measured by the ferrozine method (Stooky, 1970); and nitrite was measured using the method of Montgomery and Dymock (1961).

Metal Coupons and Weight Loss Measurements. Circular metal coupons were purchased from a commercial source (Metal Samples Co.; Munford, AL). Coupons were made of 1018 steel, had a diameter of 0.400 inches, and were $1 / 8$ inch thick. The density of the coupons was $7.87 \mathrm{~g} / \mathrm{cm}^{3}$ and the surface area was $2.63648 \mathrm{~cm}^{2}$. Prior to experiments, the coupons were weighed. Upon the conclusion of experiments, coupons were removed from the batch tests and cleaned according to ASTM standard G1-90 (for metals composed of iron and steel). The coupons were subjected to a series of six solutions, either acidic or basic and at varying temperatures. One modification was made to the ASTM method: $5 \mathrm{M}$ sodium hydroxide was used at a temperature of $100^{\circ} \mathrm{C}$ for the last cleaning step. The coupons were then rinsed in deionized water, allowed to dry at room temperature overnight in a dessicator, and then weighed the next day. The corrosion rate of the metal coupons were calculated according to the following formula:

Corrosion Rate $=(\mathrm{K} \times \mathrm{W}) /(\mathrm{A} \times \mathrm{T} \times \mathrm{D})$

where:

$\mathrm{K}=3,450,000$ (constant used to determine corrosion rate in mils per year) 
$\mathrm{T}=$ time of exposure $(\mathrm{h})$

$\mathrm{W}=$ weight loss $(\mathrm{g})$

$\mathrm{D}=\operatorname{density}\left(\mathrm{g} / \mathrm{cm}^{3}\right)$

$\mathrm{A}=$ surface area $\left(\mathrm{cm}^{2}\right)$

Experiments. Sterile 125-ml serum bottles were filled with $99 \mathrm{ml}$ of anaerobic growth media and a metal coupon. The media was amended with $1 \mathrm{ml}$ of 1,5 , or $10 \%$ of each pepper extract; the final concentrations of the extracts were therefore $0.01 \%, 0.05 \%$, and $0.1 \%$. The flasks were swirled to mix the extract and media. The media was inoculated with $1 \mathrm{ml}$ of starter bacteria culture and the flasks were swirled again to distribute the organisms. Immediately thereafter samples were withdrawn to estimate the initial bacterial culture density and the initial concentrations of protein, sulfide, iron (II), and nitrite as previously described. Samples were withdrawn aseptically at bi-weekly intervals to assay for culture density and metabolites. The experiments were concluded after 6 weeks and the coupons' weight loss was measured. Control cultures - inoculated but lacking pepper extracts - and sterile (non-inoculated) media controls were also performed. Figure 1 shows a diagram of the batch test set-up. Table 1 shows the test matrix. Each X represents a batch test. Each test was performed in triplicate.

Table 1. Summary of Batch Tests.

\begin{tabular}{|c|c|c|c|c|c|c|c|c|c|c|}
\hline & \multicolumn{3}{|c|}{ Extract 1 } & \multicolumn{3}{c|}{ Extract 2 } & \multicolumn{3}{c|}{ Extract 3 } & \multicolumn{3}{c|}{$\begin{array}{c}\text { Bacteria } \\
\text { Control }\end{array}$} \\
\hline & $0.01 \%$ & $0.05 \%$ & $0.1 \%$ & & $0.01 \%$ & $0.05 \%$ & $0.1 \%$ & $0.01 \%$ & $0.05 \%$ & \\
\hline \begin{tabular}{c} 
D. vulgaris \\
\hline $\begin{array}{c}C . \\
\text { denitrificans }\end{array}$
\end{tabular} & $\mathrm{X}$ & $\mathrm{X}$ & $\mathrm{X}$ & & $\mathrm{X}$ & $\mathrm{X}$ & $\mathrm{X}$ & $\mathrm{X}$ & $\mathrm{X}$ & $\mathrm{X}$ \\
\hline & & & & $\mathrm{X}$ & $\mathrm{X}$ & $\mathrm{X}$ & $\mathrm{X}$ & $\mathrm{X}$ & $\mathrm{X}$ \\
\hline
\end{tabular}


Figure 1. Design of the Batch Tests

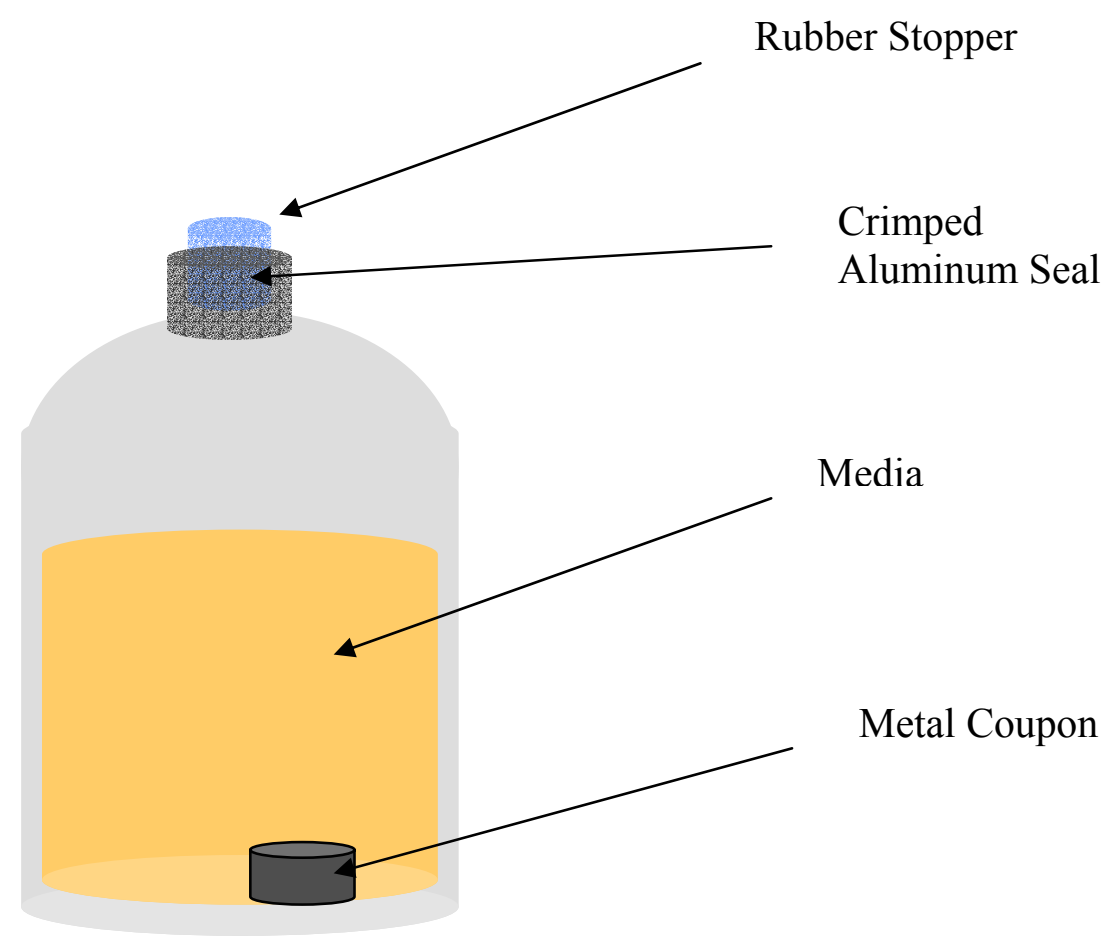




\section{RESULTS AND DISCUSSION}

Corrosion, caused by D. vulgaris, was inhibited by the presence of the pepper extracts. The corrosion rates for the pepper extract-treated batch tests was similar to the sterile media control (rate $=1.5$ mils yr-1); therefore, the corrosion observed in the batch tests was due to the media itself and not the action of the bacteria. The corrosions rates of $D$. vulgaris batch tests were almost 3-fold lower in tests treated with the respective extracts than tests in which no extract was added (Figure 2). There was no significant difference between the 3 extracts with regards to inhibiting corrosion; the average corrosion rate for each of the three extracts ranged

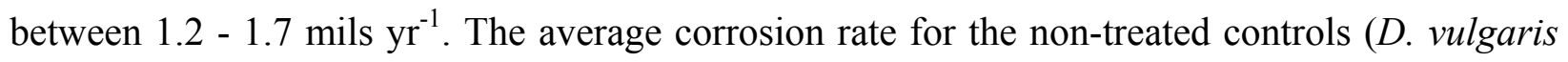

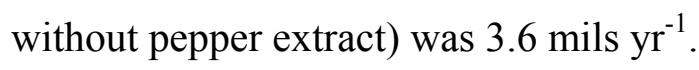

The mode of inhibition is most likely toxicity of the pepper extracts towards $D$. vulgaris. As the "cells/ml, initial" data in Table 2 show, approximately $95 \%$ of the inoculated bacteria are killed by extract 1 at $0.01 \%(20,378$ cells/ml vs. 436,000 in the no-extract control); the efficiency of killing is even higher (>99.99\%) in all other extracts, and in higher concentrations of extract $\# 1$. This result is significant because it indicates that with a very brief contact time of less than one minute the three pepper extracts tested here are capable of killing $\boldsymbol{D}$. vulgaris. This important observation should be confirmed with additional testing. At the conclusion of the experiment, all of the extract-treated cultures are below the detection limit for D. vulgaris; assuming a detection limit of 1 cell $/ \mathrm{ml}$, the total population in each of these cultures must be less than 100 viable cells (vs. over 100,000 in the controls). One question which still must be addressed is that the MPN method employed here is restricted to counting planktonic (i.e. free-living) bacteria; methods for addressing sessile (biofilm-attached) bacteria are being evaluated, and could be employed in future experiments. There was little sulfide produced indicating that metabolic activity of $D$. vulgaris was inhibited in these conditions as well. The protein data and the sulfide data are consistent with the MPN data indicating that the D. vulgaris cells were killed by exposure to the pepper extracts so that no corrosion or production of metabolites was observed that differed significantly from sterile controls. Dissolved iron $\left(\mathrm{Fe}^{2+}\right)$ increased from initial values in most tests, which could suggest that that the organisms might be able to survive by utilizing iron as an electron acceptor; however, the fact that this value also increases substantially in the non-inoculated control (presumably due to the "baseline" corrosion/deterioration of the coupon) makes this difficult to substantiate. 
Table 2. Chemical concentrations of Desulfovibrio vulgaris cultures treated with solutions of Pepper Extracts from 3 separate pepper plant species. The final concentrations of the extracts were $0.01,0.05$, and $0.1 \%$. Control cultures with bacteria but lacking pepper extracts (designated as CON Inoc) and sterile media controls that contain no bacteria or pepper extract (designated as CON N-I) were also conducted.

\begin{tabular}{|c|c|c|c|c|c|c|c|c|c|c|c|c|c|}
\hline $\begin{array}{l}\text { Pepper } \\
\text { Extracts }\end{array}$ & $\begin{array}{c}\text { Extract } \\
\text { Conc. } \\
\text { (Final) }\end{array}$ & $\begin{array}{c}\mathrm{pH} \\
\text { Initial }\end{array}$ & $\begin{array}{l}\mathrm{pH}, \\
\text { Final }\end{array}$ & $\begin{array}{c}\text { Protein } \\
\text { (mg/ml), } \\
\text { Initial }\end{array}$ & $\begin{array}{c}\text { Protein } \\
\text { (mg/ml), } \\
\text { Final }\end{array}$ & $\begin{array}{l}\text { Nitrite } \\
(\mathrm{mM}), \\
\text { Initial }\end{array}$ & $\begin{array}{c}\text { Nitrite } \\
(\mathrm{mM}), \\
\text { Final }\end{array}$ & $\begin{array}{c}\text { Sulfide } \\
\text { (mM), } \\
\text { Initial }\end{array}$ & $\begin{array}{c}\text { Sulfide } \\
\text { (mM), } \\
\text { Final }\end{array}$ & $\begin{array}{l}\text { Iron } \\
\text { (mM), } \\
\text { Initial }\end{array}$ & $\begin{array}{c}\text { Iron } \\
\text { (mM), } \\
\text { Final }\end{array}$ & $\begin{array}{l}\text { Cells/ml, } \\
\text { Initial }\end{array}$ & $\begin{array}{c}\text { Cells/ml, } \\
\text { Final }\end{array}$ \\
\hline xulat I & $1 \%$ & 7.0 & 7.0 & .0090 & 0989 & .0000 & 0.0000 & 0.0000 & 0.1 & 0.0055 & 0.0214 & 0,378 & 0 \\
\hline Extract 1 & $05 \%$ & 7.0 & 7.0 & 134 & 1046 & 0.0000 & 0.0000 & 0.0000 & 0.1 & 0.0064 & 0.0231 & 334 & 0 \\
\hline Extract 1 & $0 \%$ & 7.0 & 7.0 & 0057 & 1146 & 0.0000 & 0.0000 & 0.0000 & 0.1 & 0.0067 & 0.0274 & 43 & 0 \\
\hline Extract 2 & $0.01 \%$ & 7.0 & 7.0 & 4778 & 0.5712 & 0.0000 & 0.0000 & 0.0000 & 0.0000 & 0.0079 & 0.0207 & 43 & 0 \\
\hline Extract 2 & $0.05 \%$ & 7.0 & 7.0 & 0.4977 & 0.4464 & 0.0000 & 0.0000 & 0.0000 & 0.0000 & 0.0096 & 0.0134 & 0 & 0 \\
\hline Extract 2 & $0.10 \%$ & 7.0 & 7.0 & 0.5068 & 0.4352 & 0.0000 & 0.0000 & 0.0000 & 0.0000 & 0.0011 & 0.0146 & 0 & 0 \\
\hline Extract 3 & $0.01 \%$ & 7.0 & 7.0 & 05 & 864 & 0.0000 & 0.0000 & 000 & 000 & 0.0086 & 0.0085 & 9 & 0 \\
\hline Extract 3 & $0.05 \%$ & 7.0 & 7.0 & 0.6714 & 0.5491 & 0.0000 & 0.0000 & 0.1 & 0.0000 & 0.0151 & 0.0080 & 0 & 0 \\
\hline Extract 3 & $0.10 \%$ & 7.0 & 7.0 & 0.6995 & 0.5370 & 0.0000 & 0.0000 & 0.2 & 0.0000 & 0.0189 & 0.0082 & 1 & 0 \\
\hline CON (Inoc) & $x x$ & 7.0 & 7.5 & 0.3873 & 2.3908 & 0.0000 & 0.0000 & 0.0000 & 1.4 & 0.0006 & 0.0331 & 436,275 & $>100,000$ \\
\hline $\operatorname{CON}(\mathrm{N}-\mathrm{I})$ & $x x$ & 7.0 & 7.5 & 0.0000 & 0.0000 & 0.0000 & 0.0000 & 0.0000 & 0.0000 & 0.0000 & 0.0144 & 0 & 0 \\
\hline
\end{tabular}


Figure 2. Corrosion Rates of Desulfovibrio vulgaris cultures treated with solutions of Pepper Extracts from 3 separate pepper plant species. The final concentrations of the extracts were 0.01 , 0.05 , and $0.1 \%$. Control cultures (with bacteria but lacking pepper extracts) and sterile media controls (no bacteria, no extract) were also conducted.

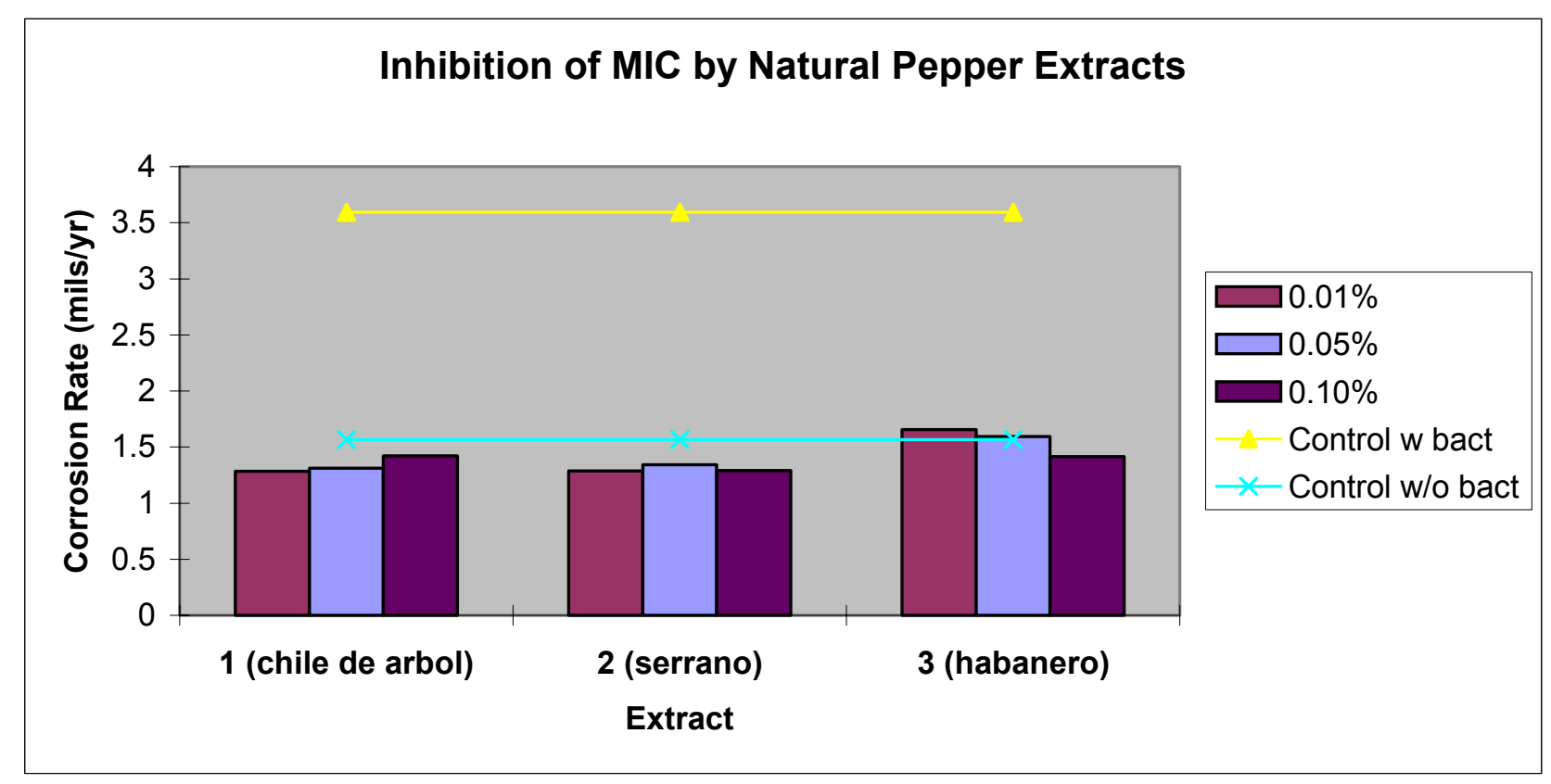

Corrosion rates by $C$. denitrificans were not inhibited by the presence of the pepper extracts. In most cases, corrosion rates were actually higher than rates observed in non-treated control cultures and sterile media controls (Figure 3). The average corrosion rate for the $C$.

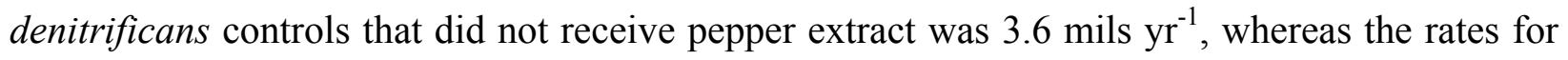
the extract-treated tests ranged from $2.4-9.3 \mathrm{mil} \mathrm{yr}^{-1}$. The organic acids in the extracts may have been utilized as carbon sources or electron donor by $C$. denitrificans cells; additional tests would need to be conducted to determine whether this was actually the case. The presence of the pepper extracts may inhibit nitrate reduction by $C$. denitrificans (Table 3). Concentrations of nitrite, the first metabolite of the denitrification pathway, increased as much as 10-fold in the batch tests after 2 weeks (Table 3 ) when pepper extract was present, but no nitrate accumulation was observed in the absence of pepper extract. At 4- and 6-weeks, the nitrite levels had returned to initial concentration values indicating that the cells were using nitrite as an electron acceptor (data not shown). Protein levels also increased, as did culture density in most samples, but not to 
comparable levels. Not surprisingly, sulfide levels were below detection; however, iron (II) concentration did increase, suggesting that iron may have served as an alternate electron acceptor for the organisms (Table 3). The $\mathrm{pH}$ of the cultures decreased from 7 , at the onset of the incubation, to approximately 6 . The slight acidity may be one reason for the increased corrosion rates in these cultures. 
TABLE 3. CHEMICAL CONCENTRATIONS OF COMOMONAS DENITRIFICANS CULTURES TREATED WITH SOLUTIONS OF PEPPER EXTRACTS FROM 3 SEPARATE PEPPER PLANT SPECIES. The final concentrations of the extracts were $0.01,0.05$, and $0.1 \%$. Control cultures with bacteria but lacking pepper extracts (designated as CON Inoc) and sterile media controls that contain no bacteria or pepper extract (designated as CON N-I) were also conducted.

\begin{tabular}{|c|c|c|c|c|c|c|c|c|c|c|c|c|c|}
\hline $\begin{array}{l}\text { Pepper } \\
\text { Extract }\end{array}$ & $\begin{array}{c}\text { Extract } \\
\text { Conc. } \\
\text { (Final) }\end{array}$ & $\underset{\text { Initial }}{\mathrm{pH}}$ & $\begin{array}{c}\mathrm{pH}, \\
\text { Final }\end{array}$ & $\begin{array}{c}\text { Protein } \\
\text { (mg/ml), } \\
\text { Initial }\end{array}$ & $\begin{array}{c}\text { Protein } \\
\text { (mg/ml), } \\
\text { Final }\end{array}$ & $\begin{array}{l}\text { Nitrite } \\
(\mathrm{mM}), \\
\text { Initial }\end{array}$ & $\begin{array}{c}\text { Nitrite } \\
(\mathrm{mM}), 2 \\
\text { weeks }\end{array}$ & $\begin{array}{l}\text { Sulfide } \\
\text { (mM), } \\
\text { Initial }\end{array}$ & $\begin{array}{c}\text { Sulfide } \\
\text { (mM), } \\
\text { Final }\end{array}$ & $\begin{array}{l}\text { Iron } \\
\text { (mM), } \\
\text { Initial }\end{array}$ & $\begin{array}{c}\text { Iron } \\
(\mathrm{mM}), \\
\text { Final }\end{array}$ & $\begin{array}{c}\text { cfu/ml, } \\
\text { Initial }\end{array}$ & $\begin{array}{c}\text { cfu/ml, } \\
\text { Final }\end{array}$ \\
\hline Extract 1 & $0.01 \%$ & 6.5 & 7.5 & 0.2217 & 0.3420 & 0 & 0 & 0 & 0.0000 & 0.0080 & 0.0126 & 0 & 0 \\
\hline Extract 1 & $0.05 \%$ & 6.5 & 7.0 & 0.2817 & 0.3827 & 0 & 8 & 0 & 0.0000 & 0.0055 & 0.0328 & 0 & 211667 \\
\hline Extract 1 & $0.10 \%$ & 6.5 & 6.0 & 0.2647 & 1.7640 & 0.1 & 2.7 & 0.0001 & 0.0000 & 0.0065 & 0.0787 & & $\begin{array}{l}119500 \\
0\end{array}$ \\
\hline Extract 2 & $0.01 \%$ & 6.5 & 6.3 & 0.3765 & 0.3505 & 0.0004 & 4 & 0.0001 & 0 & 0.0125 & 0.0762 & 35100 & 475000 \\
\hline Extract 2 & $0.05 \%$ & 6.5 & 6.2 & 0.3756 & 0.3978 & 0.0005 & 2.4 & 0.0001 & 0 & 0.0128 & 0.0771 & 43167. & $\begin{array}{l}343133 \\
3\end{array}$ \\
\hline Extract 2 & $0.10 \%$ & 6.5 & 6.1 & 0.3841 & 0.3774 & 0.0003 & 1.5 & 0.0001 & 0 & 0.0055 & 0.0796 & 115 & 406500 \\
\hline Extract 3 & $0.01 \%$ & 6.5 & 6.0 & 0.3537 & 0.5687 & 0 & 0.3 & 0.0001 & 0.0002 & 0.0103 & 0.1347 & 26033 & 935000 \\
\hline Extract 3 & $0.05 \%$ & 6.5 & 6.2 & 0.3662 & 0.6211 & 0.1 & 0.3 & 0.0001 & 0.0002 & 0.0122 & 0.1266 & 5763 & 628333 \\
\hline Extract 3 & $0.10 \%$ & 6.5 & 6.1 & 0.5022 & 0.7868 & 0 & 0.5 & 0.0002 & 0.0003 & 0.0171 & 0.1199 & 63 & 913333 \\
\hline Con (Inoc) & $x x$ & 7.0 & 6.0 & 0.0467 & 0.4037 & 0 & 0.1 & 0.0003 & 0 & 0.0059 & 0.0723 & 4227 & $\begin{array}{l}883333 \\
3\end{array}$ \\
\hline Con $(\mathrm{N}-\mathrm{I})$ & $x x$ & 7.0 & 7.0 & 0.1125 & 0 & 0 & 0 & 0 & 0 & 0.0000 & 0.0144 & 0 & \\
\hline
\end{tabular}


Figure 3. Corrosion Rates of Comomonas denitrificans cultures treated with stock solutions of 1, 5 , and $10 \%$ Pepper Extracts from 3 separate pepper plant species. The final concentrations of the extracts were $0.01,0.05$, and $0.1 \%$. Control cultures (with bacteria but lacking pepper extracts) and sterile media controls (no bacteria) were also conducted.

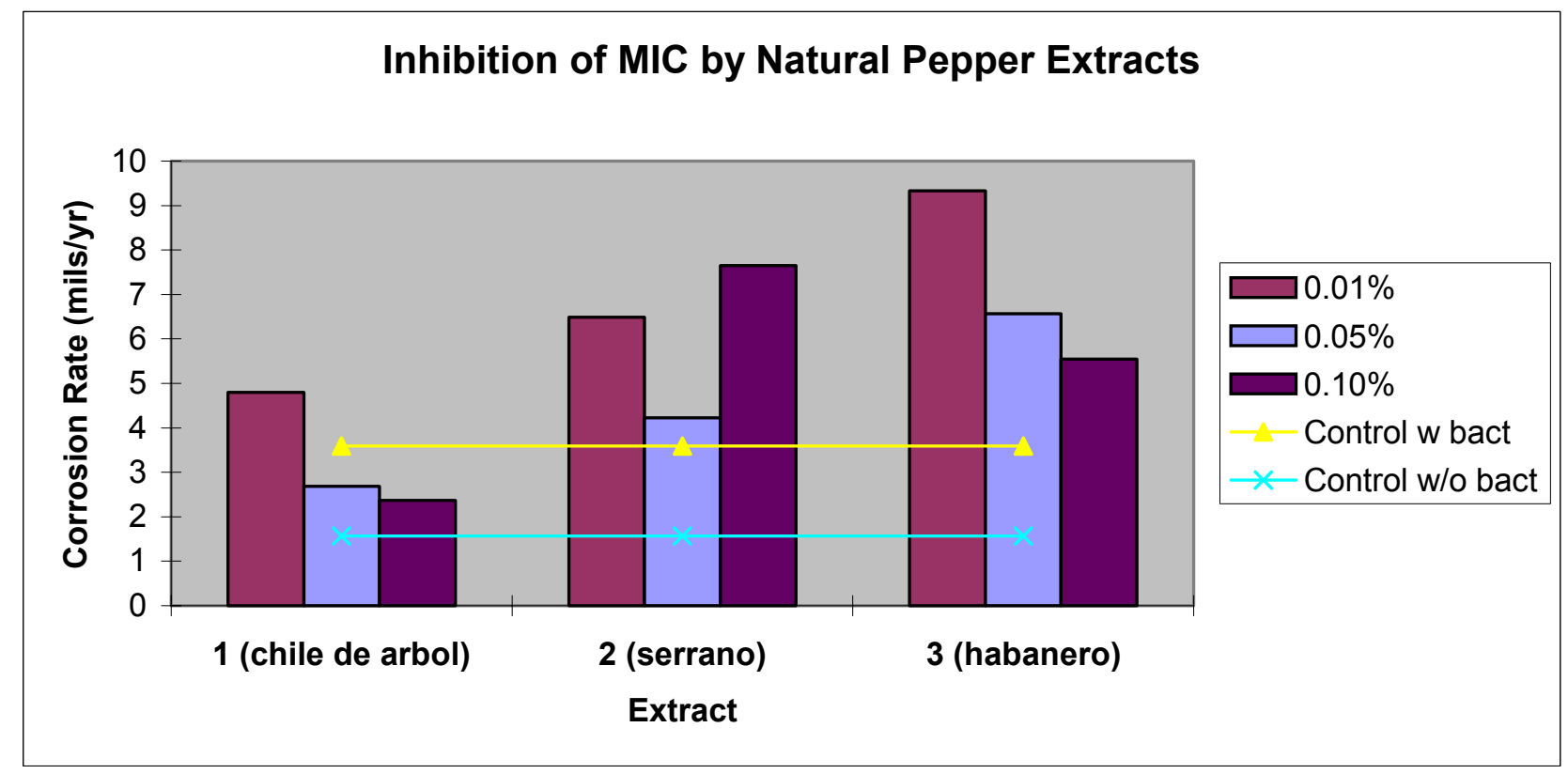




\section{CONCLUSIONS AND FUTURE EXPERIMENTS}

Results were obtained that indicate that pepper extracts appear to be rapid acting biocides capable of killing at least some sulfate reducing bacteria immediately. While denitrifying bacteria do not appear to be killed by pepper extract they may be metabolically inhibited as indicated by an accumulation of nitrite in many of the samples treated with pepper extract. The increased rate of metal corrosion observed when the denitrifying bacteria are exposed to pepper extracts is unexpected and requires further investigation. Corrosion experiments similar to those described above, are currently being conducted with mixed microbial cultures obtained from a natural gas pipeline in Colorado. Samples are being assessed for the effectiveness of the pepper extracts to kill mixed cultures of bacteria and to influence the rate of corrosion caused by mixed bacterial cultures. Results from mixed culture experiments will be available in a subsequent report. In addition, we are testing the efficacy of the pepper extracts when other biocides (i.e., ammonium cerium nitrate) are present in mixed cultures and pure cultures of corrosionassociated microorganisms. 


\section{REFERENCES}

ASTM G1-90, "Standard Practice for Preparing, Cleaning, and Evaluating Corrosion Test Specimens," ASTM International. 1999.

Chatelus, C., P. Carrier, P. Saignes, M.F. Libert, Y. Berlier, P.A. Lespinat, G. Fauque and J. Legall. 1987. Hydrogenase activity in aged, nonviable Desulfovibrio vulgaris cultures and its significance in anaerobic biocorrosion. Appl Environ Microbiol. 53:1708-1710.

Clesceri, L. S., A. E. Greenberg and A. D. Easton. 1998. Standard Methods for the Examination of Water and Wastewater. American Public Health Association, Washington, DC. p. 3-59.

Daulton T. L., B. J. Little, K. L. Lowe and J. Jones-Meehan. 2002. Electron energy loss spectroscopy techniques for the study of microbial chromium (VI) reduction. J Microbiol Methods 50:39-54.

Kholodenko, V.P., S.K. Zhigletsova, V.A. Chugunov, V.B. Rodin, V.S. Kobelev and S.V. Karpov. 2000. Chemical-microbiological diagnosis of stress-corrosive damage to pipelines. Prikl Biokhim Mikrobiol. 36:685-693.

Klee, A. J. 1996. MOST PROBABLE NUMBER CALCULATOR@ Version 4.04, United States Environmental Protection Agency, www.epa.gov/nerlcwww/other/htm. Cincinnati, OH

Lowry, O.H., N.J. Rosebrough, A.L. Farr, and R.J. Randall. 1951. Protein measurements with the Folin phenol reagent. J Biol Chem 193:265-275.

Montgomery, H.A.C. and J.F. Dymock. 1961. The determination of nitrite in water. Analyst (London) 86:414-416.

Stooky, L.L. 1970. Ferrozine: a new spectrophotometric reagent for iron. Anal Chem 42:779782 .

Zhu, X.Y., J. Lubeck and J.J. Kilbane II. 2003. Characterization of microbial communities in gas industry pipelines. Appl Environ Microbiol. 69:5354-5363. 